\title{
DO GOOD INSTITUTIONS AND ECONOMIC UNCERTAINTY MATTER TO FOREIGN DIRECT INVESTMENT?
}

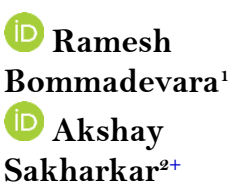

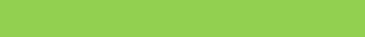

Article History

Received: 5 February 2021

Revised: 22 March 2021

Accepted: 7 May 2021

Published: 2 June 2021

\section{Keywords}

FDI inflows

Institutional quality

Domestic economic policy

uncertainty

Sequential (two-stage) estimation.

JEL Classification:

C51; D81; E02; F21.

\author{
${ }^{\prime}$ Professor, Goa Business School, Goa University, India. \\ Email:brames@rediffmail.com Tel:(+91)9511840473 \\ ${ }^{2}$ Research Scholar, Goa Business School, Goa University, Taleigao Plateau, \\ Goa, India. \\ Email:akshaysakharkar2018@gmail.com Tel:(+91)9158651479
}

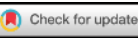

This study investigates the effects of institutional quality, economic policy uncertainty and other key fundamental factors on foreign direct investment (FDI) inflows for a sample of 22 economies from 2000 to 2019. First, the quality of institutional infrastructure in the host country matter greatly to FDI inflows. Second, a subservient increase in the Economic Policy Uncertainty (EPU) growth rates adversely affects FDI inflows. Additionally, we found that macroeconomic fundamentals pertaining to the level of financial openness, exchange rate stability and financial development in the host country are of great importance to FDI inflows. In essence, the findings from our study suggest that the improvement of macroeconomic fundamentals in conjunction with robust and strong institutional infrastructure can contribute to the moderation of economic policy uncertainty, which deters FDI inflows.

Contribution/Originality: This study contributes significantly to the growing literature on determinants of FDI inflows by examining the critical roles of institutions, economic policy uncertainty and other key decisive factors in FDI decisions by applying the dynamic panel data estimations proposed by Kripfganz (2017) as a distinct methodology alongside the two-step GMM system proposed by Blundell \& Bond (1998) on a wider selection of countries.

\section{INTRODUCTION}

The effects of good institutions and time-varying economic uncertainty on macro economies have attracted the attention of researchers in recent years, especially after the global meltdown as a consequence of global financial crisis alongside various other events, such as Brexit. The report presented by the OECD (2002) advocates the role of enabling institutional environments to reap the maximum benefits from FDI. The literature on FDI began to primarily focus on the importance of institutions in attracting foreign investments, thus suggesting why quality matters. According to Acemoglu, Johnson, \& Robinson (2005) and Rodrik, Subramanian, \& Trebbi (2004), countries with a good quality of institutions, and that promote property rights and rule of law, create better economic prospects making the country more attractive to foreign investors. Whereas poor quality of institutions can deter foreign capital inflows as it poses a threat to investments as FDI has a very high level of sunk costs, which make foreign enterprises more reluctant to enter new foreign markets unless investment in these markets entails low levels of risk and uncertainty. With regard to uncertainty, several studies have documented the adverse effects of 
rising uncertainty on macroeconomic variables ${ }^{1}$. Particularly, there is a large amount of literature that focuses on the effects of uncertainty on financial and production variables ${ }^{2}$. Specific literature also emerged alongside this which shows that high EPU in a country reduces the rate of investments (Baker, Bloom, \& Davis, 2016; Gulen \& Ion, 2016), lowers domestic production (Caggiano, Castelnuovo, \& Figueres, 2017; Karnizova \& Li, 2014) and decreases stock returns (Arouri, Estay, Rault, \& Roubaud, 2016).

There are several aspects to be considered when analyzing the drivers of FDI flows into a country. This paper focuses on twin factors, namely the quality of institutions in the host countries and domestic EPU levels. The literature also suggests several other key factors such as growth (Bevan \& Estrin, 2004; S Globerman, Shapiro, \& Tang, 2006), exchange rate (Bevan \& Estrin, 2004; Hannan, 2018; Nier, Sedik, \& Mondino, 2014) and trade (International Monetary Fund, 2010; McQuade \& Schmitz, 2017; Milesi-Ferretti \& Tille, 2011). The aforementioned determinants are closely related to the EPU shocks. These factors are adversely affected at times of high levels of domestic EPU (Bernal, Gnabo, \& Guilmin, 2016; Karnizova \& Li, 2014; Krol, 2014; Tam, 2018). Specifically, FDI flows and EPU are directly associated via domestic fundamentals that are susceptible to EPU shocks, i.e., the deterioration of domestic fundamentals after EPU shocks deters FDI inflows. Some authors, such as Steven Globerman \& Shapiro (2003) and Schneider \& Frey (1985), suggest that EPUs and host countries' institutions are closely associated. An increase in EPU is often followed by structural changes relating to policies and governance infrastructure. However, several researchers have argued both in favor and against the notion of whether institutional quality matters to FDI. In this study we reassess the debate in conjunction with the role of domestic EPU filling a significant gap in the literature and contributing to the existing literature by examining if institutions and EPU, along with other key factors such as the level of financial development, exchange rate stability and financial openness, explain why FDI flows to where it flows.

We organized this study into five broad sections following the general introduction. Section two reviews the literature on key determinants of FDI flows, followed by section three detailing the econometric methodology and data specifications. In section four we offer detailed discussions on the empirical findings, and section 5 contains the conclusion and recommendations.

\section{LITERATURE REVIEW}

Although FDI has a significant positive relationship with economic development in the host country, researchers have not yet reached a consensus on what determines FDI inflows. Several studies, such as Adamu \& Rasiah (2017); Apaydin (2009); Asiedu (2006); Borensztein, De Gregorio, \& Lee (1998); Mohamed \& Sidiropoulos (2010); Rodríguez \& Pallas (2008); Rogmans \& Ebbers (2013) and Roy \& Mandal (2012), tried to assess what determines FDI flows to a wide spectrum of economies based on the levels of development, i.e., developed and developing countries using panel, cross-sectional, and time series operations. What emerged as a key factor was economic growth, which represents market size, and according to Schneider \& Frey (1985) market size represents efficient utilization of resources and economies of scale. Several studies, such as those by Ang (2008), Bevan \& Estrin (2004), Mohamed \& Sidiropoulos (2010) and Rogmans \& Ebbers (2013), suggest economic growth as a significant driver of FDI. Several other studies highlighted other key factors such as labor force and human capital (Steven Globerman \& Shapiro, 2003; Rodríguez \& Pallas, 2008), and exchange rate (Bevan \& Estrin, 2004; Nier et al., 2014). A negative effect of inflation was reported in studies by Demirhan \& Masca (2008) and Rodríguez \& Pallas (2008) followed by a significant positive role of trade openness, as reported by Asiedu (2002); Gastanaga, Nugent, \& Pashamova (1998); Na \& Lightfoot (2006); and Rogmans \& Ebbers (2013). The studies of Hübler \&

\footnotetext{
'See Bansal, Kiku, Shaliastovich, \& Yaron (2014); Bloom (2009); Christiano, Motto, \& Rostagno (2014); Nguyen (2020); Strobel, Nguyen Thanh, \& Lee (2020) who reported negative effects of economic uncertainty on output, investments, assets and housing prices.

${ }^{2}$ See Bonaime, Gulen, \& Ion (2018); Phan, Sharma, \& Tran (2018).
} 
Keller (2010) and Rogmans \& Ebbers (2013) assert the positive role of infrastructure in attracting FDI, while Hermes \& Lensink (2003a) suggest that the level of financial development matters more.

Apart from the macroeconomic factors, the role of institutional quality has also been widely deliberated in the literature. The study by North (1990) provided for the unambiguous association between institutions and economic growth. Empirical works have demonstrated a significant positive link between the quality of institutions and economic growth (Acemoglu \& Verdier, 1998). Several studies have focused on examining how institutions affect FDI flows. One of the key factors identified by studies, such as Root (1979); Schneider \& Frey (1985) and Wei (1997), is the political factor as a key determinant of FDI flows, and over time the debate intensified with other studies, such as Jensen (2003) who suggested that democratic governments attract more FDI than others, while Li, Resnick, Li, \& Resnick (2003) argued that democracy has a negative effect on FDI flows. The most recent studies, such as one by Globerman \& Shapiro (2002), emphasized the role of other institutional factors including political, institutional, and legal environments being key drivers of FDI inflows. Following similar lines, Bénassy-Quéré, Coupet, \& Mayer (2007) found that bureaucracy, corruption, information, the banking sector, and legal institutions were significant drivers of FDI flows for the selected 52 economies. Buchanan, Le, \& Rishi (2012) also argued in favor of institutional quality as a driver of FDI and suggested that institutional quality is negatively associated to FDI volatility. Aziz (2018) also found that economic freedom, ease of doing business, and international country risk are significant drivers of FDI flows to Arab countries.

The literature dealing with the impact of EPU on the macro economy and foreign capital is limited and few studies have tried to assess the growing debate. Baker et al. (2016); Drobetz, El Ghoul, Guedhami, \& Janzen (2018) and Gulen \& Ion (2016) suggest that rising levels of EPU creates adversities for investments with a slower pace of growth rate in investments. Furthermore, Caggiano et al. (2017) and Karnizova \& Li (2014) argue that during times of high EPU episodes investors or consumers are more likely to adopt a "wait and see" attitude by postponing their investments and consumption activities leading to a decreased rate of investments and production.

\section{DATA AND ECONOMETRIC SPECIFICATIONS}

Overall, our final sample is composed of panel data from 2000 to 2019 and covers 22 countries. A unique feature of our data set is that it includes the turmoil during the 2007-2009 global financial crisis, and any analysis surrounding this crisis should offer useful insights for policy making during abnormal economic events. A list of countries selected in the sample, alongside the summary statistics and correlation matrix for the selected macroeconomic variables and variables of interest, are provided in Table 1 and Appendix Table A1, respectively. The choice of sample countries is based on the availability of data; although the macroeconomic data is available, the data for EPU series from www.policyuncertainty.com provided by Baker et al. (2016) is available only for 22 countries from 1990 to 2020. Thus, our sample comprises of 22 economies falling into the advanced and large emerging economy classifications as per the IMF. The data pertaining to macroeconomic factors were sourced from World Development Indicators (World Bank), World Governance Indicators (World Bank), Penn World Table 10.0 (Feenstra et al., 2015) and the IMF database. The EPU measure is available on a monthly basis from the 1990s consisting of three components, namely newspaper coverage of policy-related economic uncertainty of the countries, the number of federal tax code provisions set to expire in future years in the countries, and disagreement among economic forecasters as a proxy for uncertainty. Following Canh, Binh, Thanh, \& Schinckus (2020), we used the growth rate of EPU in December as a proxy for measuring the level of domestic uncertainty. The macroeconomic determinants following the literature consist of a large set of control variables including real GDP growth rate (GDPg); inflation (Inf); gross capital formation (Gcf) used as a proxy for domestic infrastructural developments; human capital ( $\mathrm{HC}) ; \mathrm{CO}_{2}$ emissions as a proxy for environmental degradation $\left(\mathrm{CO}_{2}\right)$; trade openness (Trade), real effective exchange rate (REER); and institutional quality (IQ), which represents the mean of six indicators - control of corruption, government effectiveness, regulatory quality, political stability, rule of law, and 
voice and accountability. We also used the financial openness index, financial development index and exchange rate stability index to capture the role of other key domestic fundamentals on FDI flows. All these variables are combined in the following basic econometric models.

$$
\begin{aligned}
& \text { FDIin }_{i t}=\alpha_{0}+\alpha_{1} \text { FDIin }_{i t-1}+\beta_{j} X_{i t}+\delta_{1} I Q_{i t}+\varepsilon_{i t} \\
& \text { FDIin }_{i t}=\alpha_{0}+\alpha_{1} \text { FDIin }_{i t-1}+\beta_{j} X_{i t}+\delta_{1} \text { EPU }_{i t}+\varepsilon_{i t} \\
& \text { FDIin }_{i t}=\alpha_{0}+\alpha_{1} \text { FDIin }_{i t-1}+\beta_{j} X_{i t}+\delta_{1} \text { FO_index }_{i t}+\varepsilon_{i t} \\
& \text { FDIin }_{i t}=\alpha_{0}+\alpha_{1} \text { FDIin }_{i t-1}+\beta_{j} X_{i t}+\delta_{1} \text { FD_index }_{i t}+\varepsilon_{i t} \\
& \text { FDIin }_{i t}=\alpha_{0}+\alpha_{1} \text { FDIin }_{i t-1}+\beta_{j} X_{i t}+\delta_{1} \text { ExS_index }_{i t}+\varepsilon_{i t}
\end{aligned}
$$

Where, FDIin denotes the net aggregate FDI inflows relative to the level of GDP, vector X consist of a set of control variables, IQ denotes the institutional quality, EPU relates to the level of economic uncertainty, FO_index, FD_index and ExS_index specify the financial openness index, financial development index and exchange rate stability index, respectively, and the error term is denoted by $\varepsilon_{i t}$.

Our empirical models in Equations 1 to 5 take the form of a dynamic panel data model. Unbalanced panel data and the inclusion of a lagged dependent term as a set of control variables brings a significant risk of endogeneity into our model. Many previous studies, such as those by Globerman \& Shapiro (2002) and Liu, Burridge, \& Sinclair (2002) among others, faced a similar problem. The use of an dependent variable as one of the explanatory variables has a significant influence on other independent variables, thus giving rise to the problem of endogeneity. Hence, the application of the generalized method of moments (GMM) is suggested when the model faces the problem of endogenous regressors (Nickell, 1981). A solution to the problem of endogeneity was first proposed by Anderson \& Hsiao (1982) and Arellano \& Bond (1991) who were in favor of using GMM methodology, which was further developed by Arelleno \& Bover (1995). The most recent extension to the work of Arelleno \& Bover (1995) was proposed by Blundell \& Bond (1998) and is widely used in the literature to reduce the possibility of biased estimates associated with fixed effects in short panels and also to solve the problem of endogeneity in dynamic panel data models. Although, the two-step GMM estimator is efficient in dealing with inherent endogeneity in our case, according to Windmeijer (2005), the GMM estimator often produces uncorrected standard errors which can make the estimates unreliable. In order to overcome the shortfalls, Kripfganz (2017) proposed the recently developed methodology named 'sequential (two-stage) estimation two-step GMM estimator of linear panel-data model (SELPDM)'. In the case of the SELPDM, the conventional standard errors are not valid, often when residuals from the first stage have regressed on another set of explanatory variables (often time-invariant) at the second stage.

Therefore, we first estimated Equations 1 to 5 using the two-step sequential (two-stage) estimation of linear panel-data models (SELPDM) proposed by Kripfganz (2017) as our benchmark estimation. Second, we followed the estimation based on Blundell \& Bond's (1998) two-step GMM to check for robustness'.

Table 1 below reports characteristics and computational methodologies of the whole data set (see Table A1 in the appendix for data sources). In conjecture to data properties, Figure 1 reports the average levels of FDI inflows

\footnotetext{
${ }^{3}$ The two-step GMM estimation system results are presented in the Appendix in Table A 3 and Table A4. We also performed other estimation techniques, such as pooled ordinary least squares (OLS), for additional robustness checks; however, the results were found to be insignificant in the pooled OLS estimators suggesting the existence of endogeneity in the estimations, thus SELPDM and system GMM estimators are more likely to be suitable models for the analysis.
} 
in the selected countries. Interestingly, FDI inflows are highest in Netherlands, Singapore, Ireland and Chile amidst the sample of emerging markets, with the least FDI inflows in Japan from 2000 to 2019.

Table 1. Data calculations and descriptive statistics

\begin{tabular}{l|l|c|c|c|c|c}
\hline Variable & Data Calculation & Obs. & Mean & Std. Dev. & Min. & Max. \\
\hline FDIin & Foreign direct investments as \% of GDP & 440 & 5.185 & 9.28 & -39.546 & 86.589 \\
\hline GDP_g & Real GDP growth rate (annual \%) & 440 & 2.962 & 3.318 & -9.132 & 25.163 \\
\hline Inf & Inflation (GDP Deflator annual \%) & 440 & 3.194 & 4.04 & -4.562 & 37.698 \\
\hline Gcf & Gross capital formation \% of GDP) & 439 & 24.044 & 6.311 & 10.217 & 46.66 \\
\hline Hc & $\begin{array}{l}\text { Human capital index based on years of } \\
\text { schooling and returns to education, PWT } \\
\text { 10.0 }\end{array}$ & & & & & \\
& $\mathrm{CO}_{2}$ emissions (metric tons per capita) & 392 & 7.794 & 4.936 & 0 & 20.179 \\
\hline $\mathrm{CO}_{2}$ & $\begin{array}{l}\text { Real effective exchange rate (2010 100 } \\
\text { index) }\end{array}$ & 440 & 97.587 & 13.582 & 54.058 & 153.494 \\
\hline REER & Trade openness (export-import/GDP) & 440 & 77.609 & 73.033 & 0 & 437.327 \\
\hline Trade & Mean of six governance indicators & 418 & 0.76 & 0.146 & 0.381 & 0.996 \\
\hline IQ & $\begin{array}{l}\text { Log(Country Economic Policy Uncertainty } \\
\text { index in December) }\end{array}$ & 436 & 0.05 & 0.468 & -1.526 & 1.833 \\
\hline EPU & Financial development index, IMF & 440 & 0.658 & 0.227 & 0 & 0.958 \\
\hline FD_index & Exchange rate stability index & 440 & 0.523 & 0.322 & 0.085 & 1 \\
\hline ExS_index & Financial openness index & 440 & 0.748 & 0.34 & 0 & 1 \\
\hline FO_index & & & & \\
\hline
\end{tabular}

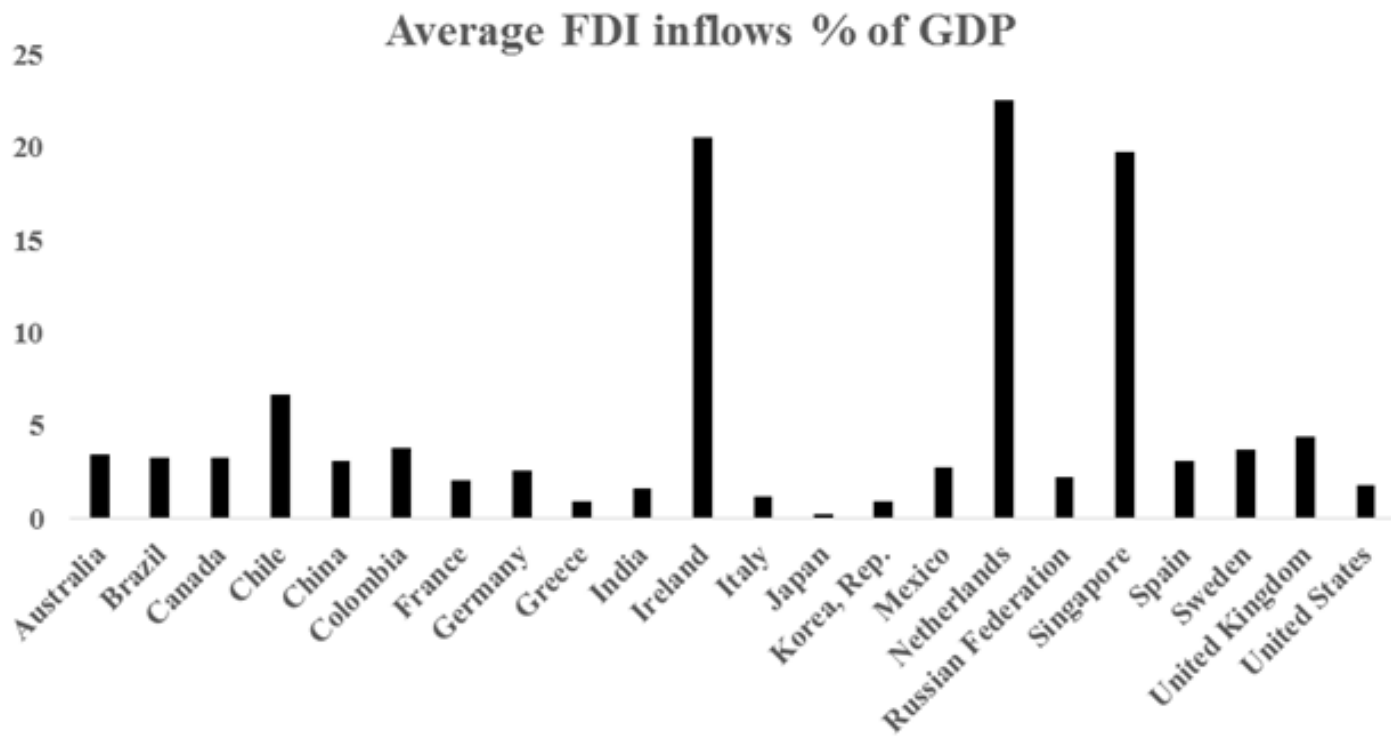

Figure 1. Average levels of FDI inflows.

Table A2 see (Appendix Table A2) reports the correlation between FDI inflows and other key economic, institutional and uncertainty related variables. The preliminary analysis indicated that FDI inflows are positively and significantly correlated with host countries GDP growth rate, trade openness and institutional quality. We also find that there exists a significant notable correlation amidst exchange rate stability and financial openness with FDI inflows. The correlation analysis however fails to draw any insights on the economic uncertainty-FDI linkage.

The results supplied in Table 2 depicts the cross-sectional dependence and unit root properties of our panel data. The cross-sectional dependence (CD) test proposed by Pesaran (2004) confirms the presence of cross-sectional dependence in our data series. Furthermore, the unit root test used on the level data series consisted of two widely used tests, namely the Im-Persaran-Shin unit root test proposed by Im, Pesaran, \& Shin (2003) and the Fisher-type test based on the Phillips-Perron type $Z$ (inverse normal) unit root test (Choi, 2001). Both tests suggested that all variables except human capital, $\mathrm{CO}_{2}$ emissions, real effective exchange rates, and trade openness contained unit 
root. Also, our test confirmed that most of our variables are integrated of order 1, i.e., I (1) but none of order 2 , i.e., I (2). The following section discusses the empirical results and findings.

Table 2. Cross-sectional dependence test and stationary tests.

\begin{tabular}{|c|c|c|c|c|c|c|}
\hline \multirow[b]{2}{*}{ Variable } & \multicolumn{2}{|c|}{$\begin{array}{c}\text { Cross-section } \\
\text { Dependence Test }\end{array}$} & \multicolumn{2}{|c|}{$\begin{array}{c}\text { Im-Pesaran-Shin Unit } \\
\text { Root Test }\end{array}$} & \multicolumn{2}{|c|}{ Fisher-type Unit Root Test } \\
\hline & $\begin{array}{l}\text { CD Test } \\
\text { Statistics }\end{array}$ & $\begin{array}{c}\text { p- } \\
\text { value }\end{array}$ & $\begin{array}{c}\text { Z-t-tilde-bar } \\
\text { Statistics }\end{array}$ & $\begin{array}{c}\mathrm{p}- \\
\text { value }\end{array}$ & $\begin{array}{c}\text { Inverse chi-squared } \\
\text { P-Statistics }\end{array}$ & p-value \\
\hline FDIin & $5.908 * * *$ & 0.0000 & -6.7491 **** & 0.0000 & $89.0305 * * *$ & 0.0001 \\
\hline GDP_g & $30.61 * * *$ & 0.0000 & $-7.4679 * * *$ & 0.0000 & $89.5285 * * *$ & 0.0001 \\
\hline Inf & $7.783^{* * * *}$ & 0.0000 & $-5.6111^{* * * *}$ & 0.0000 & $62.4720^{* * *}$ & 0.0348 \\
\hline Gcf & $6.37 * * *$ & 0.0000 & $-2.8104 * * *$ & 0.0025 & 59.0923 & 0.1045 \\
\hline $\mathrm{Hc}$ & $60.91 * * *$ & 0.0000 & 11.6812 & 1.0000 & 22.1322 & 0.9976 \\
\hline $\mathrm{CO}_{2}$ & $49.70^{* * * *}$ & 0.0000 & 5.9902 & 1.0000 & 20.2212 & 0.9992 \\
\hline REER & $6.647 * * *$ & 0.0000 & -0.1614 & 0.4359 & 40.8047 & 0.6094 \\
\hline Trade & $12.43 * * *$ & 0.0000 & 0.4209 & 0.6631 & 40.1977 & 0.6353 \\
\hline IQ & $7.626 * * *$ & 0.0000 & $-2.6627 * * *$ & 0.0039 & 43.7440 & 0.4825 \\
\hline EPU & $23.823^{* * *}$ & 0.0000 & $-12.8145^{* * * *}$ & 0.0000 & $170.8740^{* * * *}$ & 0.0000 \\
\hline FD_index & $18.992^{* * *} *$ & 0.0000 & $\mathrm{n} / \mathrm{a}$ & $\mathrm{n} / \mathrm{a}$ & 37.7526 & 0.7351 \\
\hline ExS_index & 9.641 **** & 0.0000 & $\mathrm{n} / \mathrm{a}$ & $\mathrm{n} / \mathrm{a}$ & $59.5008^{*}$ & 0.0594 \\
\hline FO_index & $53.495^{* * * *}$ & 0.0000 & $\mathrm{n} / \mathrm{a}$ & $\mathrm{n} / \mathrm{a}$ & 46.3165 & 0.3769 \\
\hline
\end{tabular}

\section{RESULTS AND DISCUSSION}

The results of our econometric models are shown in Table 3 and Table 4. The results correspond to the benchmark estimation methodology of the sequential (two-stage) estimation of linear panel-data model (SELPDM) proposed by Kripfganz (2017). Alternatively, we also tested our models using the conventional two-step GMM method of Blundell \& Bond (1998) (see Appendix Table A3 and A4 for the results). Interestingly, for both of our estimations, all the p-values of $\operatorname{AR}(2)$, which corresponds to the presence of second order serial correlation, and the Hansen test, which suggests over-identification of instruments, are statistically insignificant indicating that our estimations are consistent and unbiased (Roodman, 2006).

Table 3 provides the empirical results. The importance of institutional quality has been widely debated in the growing literature; the level of corruption and political instability directly correlates to a country's institutional quality. According to Cleeve (2008), corruption directly affects institutions and political instability which limits the development prospects. Sahu (2008) further argued that unequal distribution of resources create revolt, which restricts the development of more efficient economic and political institutions further restraining FDI inflows. Our empirical results pertaining to the role of institutional quality on FDI inflows advocates that FDI flows are sensitive to institutional quality in the host countries. We found a positive association between institutional quality and FDI flows, a single percentage point increase in the quality of institutions in the host country increases FDI inflows by a significant 4.5996 percentage points. This observation is in line with the conjecture that poor institutions impede FDI inflows. Foreign investors are unwilling to invest in countries where institutions are weak, and corruption, nepotism and red tapism is on the rise, which escalate the cost of doing business (Buchanan et al., 2012; Mengistu \& Adhikary, 2011). Furthermore, our empirical findings suggest that countries with stable and robust institutions attract more FDI than others. The interaction term between FDI inflows and institutional quality reveals significant positive results. The coefficient value of 1.1866 percentage points confirms our standalone estimate of the relevance of institutional quality to FDI. In essence, a stable institutional environment coupled with ample FDI inflows can generate positive synergies for growth and development as well as create feedback effect which can attract more FDI. 
Table 3. Institutional quality, economic policy uncertainty and FDI inflows (sequential (two-stage) estimation of linear panel data models).

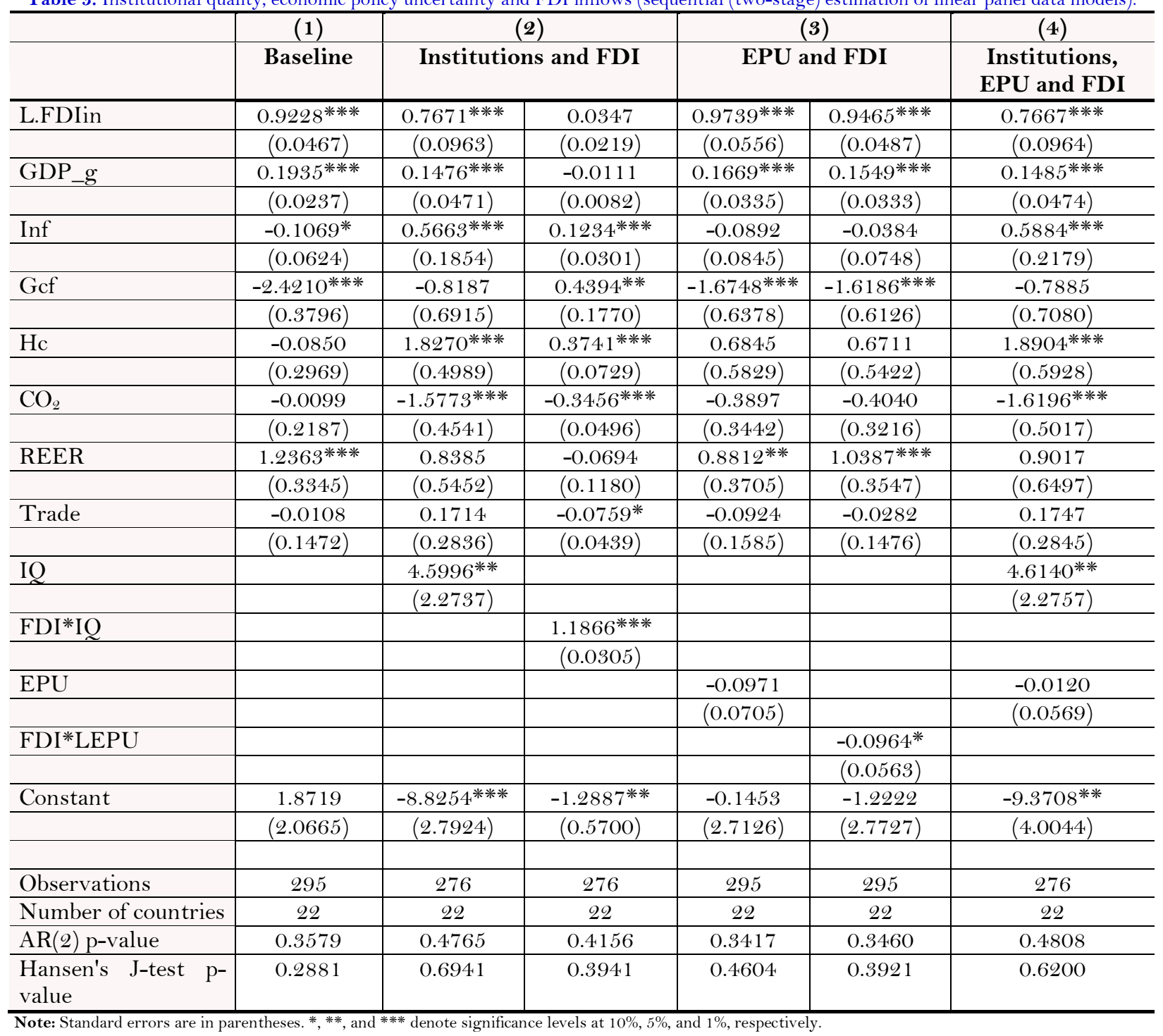

The literature dealing with the impact of domestic economic policy uncertainty on the macro economy and foreign capital is very limited; only a few studies have tried to assess the growing debate (Baker et al., 2016; Caggiano et al., 2017; Drobetz et al., 2018; Gulen \& Ion, 2016; Karnizova \& Li, 2014). We found that a subservient increase in the EPU growth rate in the host country reduces the FDI inflows into that country; more specifically, a one percentage point increase in EPU brings about a 0.0971 percentage point fall in FDI inflows. Although the coefficient lacks significance ${ }^{4}$, the results are in line with the conjecture that high EPU episodes negatively affect FDI owing to the "wait and see" attitude of foreign investors, which results in the deferment of investment decisions; the corrosion in growth prospects of the country, which further deters FDI inflows; and sinking FDI investments due to increased uncertainty concerning future political, institutional and legal environments in the host country. We also assessed the roles of interaction factors between FDI and EPU, and we found the coefficient to be significant and negative at a 0.2093 percentage point. The results submit that domestic policy uncertainty is a significant decisive factor for FDI investments. At times of high fluctuations in EPU, FDI falls and otherwise.

${ }^{4}$ The coefficient of EPU was found to be negative and highly significant in our robust estimation (see Appendix Table A3). 
Table 4. Financial openness, exchange rate stability, financial development and FDI inflows (sequential (two-stage) estimation of linear panel data models).

\begin{tabular}{|c|c|c|c|}
\hline & $(1)$ & $(2)$ & $(3)$ \\
\hline & Financial Openness & Exchange Rate Stability & Financial Development \\
\hline \multirow[t]{2}{*}{ L.FDIin } & $1.0208^{* * * *}$ & $1.0151^{* * * *}$ & $0.7919^{* * * *}$ \\
\hline & $(0.0750)$ & $(0.0835)$ & $(0.0626)$ \\
\hline \multirow[t]{2}{*}{ GDP_g } & $0.0966^{*}$ & $0.1514 * * *$ & $0.1734 * * *$ \\
\hline & $(0.0539)$ & $(0.0294)$ & $(0.0451)$ \\
\hline \multirow[t]{2}{*}{ Inf } & $0.6124^{* *}$ & $0.2304 * * *$ & $0.2914^{*}$ \\
\hline & $(0.3008)$ & $(0.0682)$ & $(0.1744)$ \\
\hline \multirow[t]{2}{*}{ Gcf } & $3.1301 * * *$ & $-0.6949 * * *$ & $-2.1871^{* * * *}$ \\
\hline & $(0.9564)$ & $(0.2296)$ & $(0.6061)$ \\
\hline \multirow[t]{2}{*}{$\mathrm{Hc}$} & $1.2977 * * *$ & $1.7977 * * *$ & 0.7425 \\
\hline & $(0.4655)$ & $(0.4464)$ & $(0.4537)$ \\
\hline \multirow[t]{2}{*}{$\mathrm{CO}_{2}$} & $-1.6047 * * *$ & $-0.9249^{* * * *}$ & $-0.8296^{* *}$ \\
\hline & $(0.4868)$ & $(0.2300)$ & $(0.3400)$ \\
\hline \multirow[t]{2}{*}{ REER } & $-1.4722 * *$ & & $2.0130 * * *$ \\
\hline & $(0.6588)$ & & $(0.3443)$ \\
\hline \multirow[t]{2}{*}{ Trade } & $-0.7078^{* * *} *$ & $-0.3393 * *$ & $0.6208 * * *$ \\
\hline & $(0.1550)$ & $(0.1604)$ & $(0.2178)$ \\
\hline \multirow[t]{2}{*}{ FO_index } & $5.8658 * * *$ & & \\
\hline & $(1.6113)$ & & \\
\hline \multirow[t]{2}{*}{ ExS_index } & & $2.0260^{* * * *}$ & \\
\hline & & $(0.5138)$ & \\
\hline \multirow[t]{2}{*}{ FD_index } & & & $2.0287 * *$ \\
\hline & & & $(0.9301)$ \\
\hline \multirow[t]{2}{*}{ Constant } & $-6.4824^{* *}$ & -1.8327 & $-7.4750^{* * * *}$ \\
\hline & $(2.6652)$ & $(1.1346)$ & $(2.8427)$ \\
\hline Observations & 295 & 295 & 295 \\
\hline $\begin{array}{ll}\begin{array}{l}\text { Number } \\
\text { countries }\end{array} & \text { of } \\
\end{array}$ & 22 & 22 & 22 \\
\hline $\mathrm{AR}(2) \mathrm{p}$-value & 0.3575 & 0.3402 & 0.3644 \\
\hline $\begin{array}{l}\text { Hansen's J-test p- } \\
\text { value }\end{array}$ & 0.5617 & 0.4150 & 0.5608 \\
\hline
\end{tabular}

Aside from the key determinants, our study also focused on other key drivers of FDI inflows, specifically on the roles of financial openness, exchange rate stability and financial development; Table 4 reports the empirical results. The effects of financial openness and globalization on foreign capital inflows remain controversial. The debate is persistent and remains highly inconclusive as to whether financial globalization or openness is conducive to capital inflows ${ }^{5}$. Our empirical findings on the role of financial openness in driving FDI inflows show that host countries' levels of financial openness are important. A one percentage point increase in the level of financial openness results in an increase in FDI inflows by 5.8658 percentage points. These findings are a significant contribution to the related literature. In a similar fashion, we also sought to discover if exchange rate stability and the level of financial development in the host country are pursued as key decisive factors by FDI investors. Although the literature is extensive and contains a variety of outcomes across countries and methodologies, for instance, in the context of FDI and financial development linkage, the association is ambiguous and several studies argued that FDI promotes financial development through supplementing capital requirements (Levine, 1997). Conversely, another school of thought argues that countries with inherently strong financial sectors attract more FDIs (Alfaro, Chanda, KalemliOzcan, \& Sayek, 2004; King \& Levine, 1993). Although the two views are differentiated, a wide spectrum of

${ }^{5}$ Previous studies, such as that by Montiel \& Reinhart (1999), suggest that capital control affects the composition and not the volume, whereas Asiedu, Lien, Asiedu, \& Lien (2004) found that the effects of capital control on FDIs vary over time across countries. 
literature is focused on this debate yet the findings remain inconclusive ${ }^{6}$. Our empirical results on the role of financial development suggest that the level of financial development in the host country affects FDIs and that countries with highly robust and strong financial systems attract more FDI inflows. We found that for every percentage point increase in the level of financial development FDI flows rose by 2.0287 percentage points. These robust findings are in line with the findings of previous studies (Alfaro et al., 2004; King \& Levine, 1993). We also modeled the role of exchange rate stability alongside the real effective exchange rates and found that the stability of exchange rate policy affects FDIs; for every percentage point increase in the stability of exchange rate, FDIs rose by 2.0260 percentage points.

Alongside the key drivers, the role of key macroeconomic factors is also highlighted in our estimations. We found FDI inflows to be positively correlated with the host countries' economic growth rates, which is used as a proxy for market potential. We also found that human capital, exchange rates and trade openness contribute to other key fundamental drivers of FDIs. The inclusion of carbon emissions signifies the environmental factors in the host country, and our empirics suggest a negative correlation in line with the growing literature on the quality of the FDI-environment nexus. FDIs were found to be circumventing investments into countries with poor environmental laws and pollution control measures. All our findings correlate to the findings from the two-step GMM estimation (see Appendix Table A3 and Table A4) and are in line with the literature on the determinants of FDIs.

\section{CONCLUSION}

This study contributes significantly to the growing literature on determinants of FDI inflows by examining the critical roles of institutions, economic policy uncertainty and other key decisive factors in FDI decisions using a panel of 22 developed and emerging market economies from 2000 to 2019 . By using dynamic panel data estimations proposed by Kripfganz (2017), we can add to the theory in numerous ways. First, we found that institutional quality affects FDI decisions. A stable institutional environment coupled with ample FDI inflows can generate positive synergies for growth and development as well as create a feedback effect, which attracts more FDIs. Furthermore, the effects of the level of domestic economic policy uncertainty were found to be negative on FDI flows, suggesting that a subservient increase in the EPU growth rate in the host country reduces FDI inflows. These robust findings entail the notion that instable policies can ruin business prospects. Another key finding pertains to other key fundamental factors; the empirics suggest that financial openness, exchange rate stability and financial development in the host country substantially matter to FDI inflows. FDI inflows were found to be positively correlated with all these factors in our study. The findings from our study have essential policy implications. Policy makers, particularly in developing countries, should focus on improving macroeconomic fundamentals in conjunction with robust and strong institutional infrastructure that contributes to the moderation of economic policy uncertainty which deters FDI inflows.

Funding: This study received no specific financial support.

Competing Interests: The authors declare that they have no competing interests.

Acknowledgement: Both authors contributed equally to the conception and design of the study.

\section{REFERENCES}

Acemoglu, D., Johnson, S., \& Robinson, J. A. (2005). Chapter 6 institutions as a fundamental cause of long-run growth. Handbook of Economic Growth, 1, 385-472. Available at: https://doi.org/10.1016/S1574-0684(05)01006-3.

\footnotetext{
${ }^{6}$ See Ang (2009); Bilir, Chor, \& Manova (2019); Desbordes \& Wei (2017); Donaubauer, Neumayer, \& Nunnenkamp (2020); Kumari \& Sharma (2017); Nabila Abdul Bahri \& Hakimah Haji Mohd Nor (2019); Saini \& Singhania (2018).
} 
Acemoglu, D., \& Verdier, T. (1998). Property rights, corruption and the allocation of talent: A general equilibrium approach. The Economic Journal, 108(450), 1381-1403. Available at: https://doi.org/10.1111/1468-0297.00347.

Adamu, I. M., \& Rasiah, R. (2017). On the determinants of external debt in Nigeria. SSRN Electronic Journal, 1-25. Available at: https://doi.org/10.2139/ssrn.2865568.

Aizenman, J., Chinn, M. D., \& Ito, H. (2010). The emerging global financial architecture: Tracing and evaluating new patterns of the trilemma configuration. Journal of International Money and Finance, 29(4), 615-641. Available at: https://doi.org/10.1016/j.jimonfin.2010.01.005.

Alfaro, L., Chanda, A., Kalemli-Ozcan, S., \& Sayek, S. (2004). FDI and economic growth: The role of local financial markets. Journal of International Economics, 64(1), 89-1 12. Available at: https://doi.org/10.1016/S0022-1996(03)00081-3.

Anderson, T. W., \& Hsiao, C. (1982). Formulation and estimation of dynamic models using panel data. Journal of Econometrics, 18(1), 47-82. Available at: https://doi.org/10.1016/0304-4076(82)90095-1.

Ang, J. B. (2008). Determinants of foreign direct investment in Malaysia. Journal of Policy Modeling, 30(1), 185-189.

Ang., J. B. (2009). Foreign direct investment and its impact on the Thai economy: The role of financial development. Journal of Economics and Finance, 33(3), 316-323. Available at: https://doi.org/10.1007/s12197-008-9042-6.

Apaydin, M. (2009). Analyzing FDI trends in emerging markets: Turkey vs CSEE and the Middle East. International Journal of Emerging Markets, 4(1), 72-97. Available at: https://doi.org/10.1108/17468800910931689.

Arellano, M., \& Bond, S. (1991). Some tests of specification for panel Carlo application to data: Evidence and an employment equations. The Review of Economic Studies, 58(2), 277-297. Available at: https://doi.org/10.2307/2297968.

Arelleno, M., \& Bover, O. (1995). Another look at instrumental variable estimation of error component models. Journal of Econometrics, 68(1), 29-51. Available at: https://doi.org/10.1016/0304-4076(94)01642-d.

Arouri, M., Estay, C., Rault, C., \& Roubaud, D. (2016). Economic policy uncertainty and stock markets: Long-run evidence from the US. Finance Research Letters, 18, 136-141. Available at: https://doi.org/10.1016/j.frl.2016.04.011.

Asiedu, E. (2006). Foreign direct investment in Africa: The role of natural resources, market size, government policy, institutions and political instability. World Economy, 29(1), 63-77. Available at: https://doi.org/10.1111/j.14679701.2006.00758.x.

Asiedu, E., Lien, D., Asiedu, E., \& Lien, D. (2004). Capital controls and foreign direct investment. World Development, 32(3), 479490.

Asiedu., E. (2002). On the determinants of foreign direct investment to developing countries: Is Africa different? World Development, 30(1), 107-1 19. Available at: https://doi.org/10.1016/s0305-750x(01)00100-0.

Aziz, O. G. (2018). Institutional quality and FDI inflows in Arab economies. Finance Research Letters, 25, 111-123. Available at: https://doi.org/10.1016/j.frl.2017.10.026.

Baker, S. R., Bloom, N., \& Davis, S. J. (2016). Measuring economic policy uncertainty. The Quarterly Journal of Economics, 131(4), 1593-1636. Available at: https://doi.org/10.1093/qje/qjw024.

Bansal, R., Kiku, D., Shaliastovich, I., \& Yaron, A. (2014). Volatility, the macroeconomy, and asset prices. The Journal of Finance, 69(6), 2471-2511. Available at: https://doi.org/10.1111/jofi.12110.

Bénassy-Quéré, A., Coupet, M., \& Mayer, T. (2007). Institutional determinants of foreign direct investment. World Economy, 30(5), 764-782. Available at: https://doi.org/10.1111/j.1467-9701.2007.01022.x.

Bernal, O., Gnabo, J. Y., \& Guilmin, G. (2016). Economic policy uncertainty and risk spillovers in the Eurozone. Journal of International Money and Finance, 65, 24-45. Available at: https://doi.org/10.1016/j.jimonfin.2016.02.017.

Bevan, A. A., \& Estrin, S. (2004). The determinants of foreign direct investment into European transition economies. Journal of Comparative Economics, 32(4), 775-787. Available at: https://doi.org/10.1016/j.jce.2004.08.006.

Bilir, L. K., Chor, D., \& Manova, K. (2019). Host-country financial development and multinational activity. European Economic Review, 115, 192-220. Available at: https://doi.org/10.1016/j.euroecorev.2019.02.008.

Bloom, N. (2009). The impact of uncertainty shocks. Econometrica, 77(3), 623-685. Available at: https://doi.org/10.3982/ECTA6248. 
Blundell, R., \& Bond, S. (1998). Initial conditions and moment restrictions in dynamic panel data models. Journal of Econometrics, 87(1), 115-143. Available at: https://doi.org/10.1016/So304-4076(98)00009-8.

Bonaime, A., Gulen, H., \& Ion, M. (2018). Does policy uncertainty affect mergers and acquisitions? Journal of Financial Economics, 129(3), 531-558. Available at: https://doi.org/10.1016/j.jfineco.2018.05.007.

Borensztein, E., De Gregorio, J., \& Lee, J. W. (1998). How does foreign direct investment affect economic growth? Journal of International Economics, 45(1), 115-135. Available at: https://doi.org/10.1016/So022-1996(97)00033-0.

Buchanan, B. G., Le, Q. V., \& Rishi, M. (2012). Foreign direct investment and institutional quality: Some empirical evidence. International Review of Financial Analysis, 21, 81-89. Available at: https://doi.org/10.1016/j.irfa.2011.10.001.

Caggiano, G., Castelnuovo, E., \& Figueres, J. M. (2017). Economic policy uncertainty and unemployment in the United States: A nonlinear approach. Economics Letters, 151, 31-34. Available at: https://doi.org/10.1016/j.econlet.2016.12.002.

Canh, N. P., Binh, N. T., Thanh, S. D., \& Schinckus, C. (2020). Determinants of foreign direct investment inflows: The role of economic policy uncertainty. International Economics, 161, 159-172. Available at: https://doi.org/10.1016/j.inteco.2019.11.012.

Chinn, M. D., \& Ito, H. (2006). What matters for financial development? Capital controls, institutions, and interactions. Journal of Development Economics, 81(1), 163-192. Available at: https://doi.org/10.1016/j.jdeveco.2005.05.010.

Chinn., M. D., \& Ito, H. (2008). A new measure of financial openness. Journal of Comparative Policy Analysis: Research and Practice, 10(3), 309-322. Available at: https://doi.org/10.1080/13876980802231123.

Choi, I. (2001). Unit root tests for panel data. Journal of International Money and Finance, 20(2), 249-272. Available at: https://doi.org/10.1016/S0261-5606(00)00048-6.

Christiano, L. J., Motto, R., \& Rostagno, M. (2014). Risk shocks. American Economic Revierw, 104(1), 27-65. Available at: https://doi.org/10.1257/aer.104.1.27.

Cleeve, E. (2008). How effective are fiscal incentives to attract FDI to Sub-Saharan Africa? Journal of Developing Areas, 42(1), 135-153. Available at: https://doi.org/10.1353/jda.0.0015.

Demirhan, E., \& Masca, M. (2008). Determinants of foreign direct investment flows to developing countries: A cross-sectional analysis. Prague Economic Papers, 4(4), 356-369.

Desbordes, R., \& Wei, S. J. (2017). The effects of financial development on foreign direct investment. Journal of Development Economics, 127, 153-168. Available at: https://doi.org/10.1016/j.jdeveco.2017.02.008.

Donaubauer, J., Neumayer, E., \& Nunnenkamp, P. (2020). Financial market development in host and source countries and their effects on bilateral foreign direct investment. The World Economy, 43(3), 534-556. Available at: https://doi.org/10.1111/twec.12884.

Drobetz, W., El Ghoul, S., Guedhami, O., \& Janzen, M. (2018). Policy uncertainty, investment, and the cost of capital. Journal of Financial Stability, 39, 28-45. Available at: https://doi.org/10.1016/j.jfs.2018.08.005.

Feenstra, R. C., Inklaar, R., Timmer, M. P., Aten, B., Atkeson, A., Basu, S., \& Végh, C. (2015). The next generation of the penn world table. American Economic Review, 105(10), 3150-3182. Available at: https://doi.org/10.1257/aer.20130954.

Gastanaga, V. M., Nugent, J. B., \& Pashamova, B. (1998). Host country reforms and FDI inflows: How much difference do they make? World Development, 26(7), 1299-1314. Available at: https://doi.org/10.1016/s0305-750x(98)00049-7.

Globerman, S., \& Shapiro, D. (2003). Governance infrastructure and US foreign direct investment. Journal of International Business Studies, 34(1), 19-39. Available at: https://doi.org/10.1057/palgrave.jibs.8400001.

Globerman, S., Shapiro, D., \& Tang, Y. (2006). Foreign direct investment in emerging and transition European countries. International Finance Review, 6, 431-459. Available at: https://doi.org/10.1016/S1569-3767(05)06017-6.

Globerman, S., \& Shapiro, D. (2002). Global foreign direct investment flows: The role of governance infrastructure. World Development, 30(11), 1899-1919. Available at: https://doi.org/10.1016/s0305-750x(02)001 10-9.

Gulen, H., \& Ion, M. (2016). Policy uncertainty and corporate investment. The Review of Financial Studies, 29(3), 523-564.

Hannan, S. A. (2018). Revisiting the determinants of capital flows to emerging markets--a survey of the evolving literature. IMF Working Papers No. 18/214. 
Hermes, N., \& Lensink, R. (2003a). Foreign direct investment, financial development and economic growth. Journal of Development Studies, 4O(1), 142-163. Available at: https://doi.org/10.1080/00220380412331293707.

Hübler, M., \& Keller, A. (2010). Energy savings via FDI? Empirical evidence from developing countries. Environment and Development Economics, 15(1), 59-80. Available at: https://doi.org/10.1017/S1355770X09990088.

Im, K. S., Pesaran, M. H., \& Shin, Y. (2003). Testing for unit roots in heterogeneous panels. Journal of Econometrics, 115(1), 5374. Available at: https://doi.org/10.1016/S0304-4076(03)00092-7.

International Monetary Fund. (2010). FDI flows to low-income countries: Global drivers and growth implications. IMF Working Papers, 10(132), 1. Available at: https://doi.org/10.5089/9781455201150.001.

Jensen, N. M. (2003). Democratic governance and multinational corporations: Political regimes and inflows of foreign direct investment. International Organization, 57(3), 587-616. Available at: https://doi.org/10.1017/s0020818303573040.

Karnizova, L., \& Li, J. C. (2014). Economic policy uncertainty, financial markets and probability of US recessions. Economics Letters, 125(2), 261-265. Available at: https://doi.org/10.1016/j.econlet.2014.09.018.

King, R. G., \& Levine, R. (1993). Finance, entrepreneurship and growth. Journal of Monetary Economics, 32(3), 513-542. Available at: https://doi.org/10.1016/0304-3932(93)90028-E.

Kripfganz, S. (2017). Sequential (two-stage) estimation of linear panel-data models. Paper presented at the German Stata Users' Group Meetings 2017.

Krol, R. (2014). Economic policy uncertainty and exchange rate volatility. International Finance Review, 17(2), 241-256. Available at: https://doi.org/10.1111/infi.12049.

Kumari, R., \& Sharma, A. K. (2017). Determinants of foreign direct investment in developing countries: A panel data study. International Journal of Emerging Markets, 12(4), 658-682. Available at: https://doi.org/10.1108/IJoEM-10-2014-0169.

Levine, R. (1997). Financial development and economic growth: Views and agenda. Journal of Economic Literature, 35(2), 688726. Available at: https://doi.org/10.1596/1813-9450-1678.

Li, Q., Resnick, A., Li, Q., \& Resnick, A. (2003). Reversal of fortunes: Democratic institutions and foreign direct investment inflows to developing countries. International Organization, 57(1), 175-211.

Liu, X., Burridge, P., \& Sinclair, P. J. N. (2002). Relationships between economic growth, foreign direct investment and trade: Evidence from China. Applied Economics, 34(11), 1433-1440. Available at: https://doi.org/10.1080/00036840110100835.

McQuade, P., \& Schmitz, M. (2017). The great moderation in international capital flows: A global phenomenon? Journal of International Money and Finance, 73, 188-212. Available at: https://doi.org/10.1016/j.jimonfin.2017.02.027.

Mengistu, A. A., \& Adhikary, B. K. (2011). Does good governance matter for FDI inflows? evidence from Asian economies. Asia Pacific Business Review, 17(3), 281-299. Available at: https://doi.org/10.1080/13602381003755765.

Milesi-Ferretti, G.-M., \& Tille, C. (2011). The great retrenchment: International capital flows during the global financial crisis. Economic Policy, 26(66), 289-346. Available at: https://doi.org/10.1111/j.1468-0327.2011.00263.x.

Mohamed, S. E., \& Sidiropoulos, M. G. (2010). Another look at the determinants of foreign direct investment in MENA countries: An empirical investigation. Journal of Economic Development, 35(2), 75-90. Available at: https://doi.org/10.35866/caujed.2010.35.2.005.

Montiel, P., \& Reinhart, C. M. (1999). Do capital controls and macroeconomic policies influence the volume and composition of capital flows? Evidence from the 1990s. Journal of International Money and Finance, 18(4), 619-635. Available at: https://doi.org/10.1016/S0261-5606(99)00021-2.

Na, L., \& Lightfoot, W. (2006). Determinants of foreign direct investment at the regional level in China. Journal of Technology Management in China, 1(3), 262-278. Available at: https://doi.org/10.1108/17468770610704930.

Nabila Abdul Bahri, E., \& Hakimah Haji Mohd Nor, N. (2019). Nonlinear effect of financial development and foreign direct investment in integration economies among ASEAN-5 countries following IFRS adoption. Accounting and Finance New Perspectives on Banking, Financial Statements and Reporting. Retrieved from: https://doi.org/10.5772/intechopen.86104. 
Nguyen, T. B. (2020). Macroeconomic uncertainty, the option to wait and IPO issue cycles. Finance Research Letters, $32,101100$. Available at: https://doi.org/10.1016/j.frl.2019.01.012

Nickell, S. (1981). Biases in dynamic models with fixed effects. Econometrica: Journal of the Econometric Society, 49(6), 1417-1426.

Nier, E., Sedik, T. S., \& Mondino, T. (2014). Gross private capital flows to emerging markets: Can the global financial cycle be tamed? International Monetary Fund No. 14-196.

North, D. C. (1990). Institutions, institutional change and economic performance. In Institutions, Institutional Change and Economic Performance. Retrieved from: https://doi.org/10.1017/cbo9780511808678.

OECD. (2002). Foreign direct investment for development-maximising benefits, minimising costs. Direct. Retrieved from: https://doi.org/10.1787/9789264174139-en.

Pesaran, M. H. (2004). General diagnostic tests for cross-sectional dependence in panels. Empirical Economics, 1-38.

Phan, D. H. B., Sharma, S. S., \& Tran, V. T. (2018). Can economic policy uncertainty predict stock returns? Global evidence. Journal of International Financial Markets, Institutions and Money, 55, 134-150. Available at: https://doi.org/10.1016/j.intfin.2018.04.004.

Rodríguez, X. A., \& Pallas, J. (2008). Determinants of foreign direct investment in Spain. Applied Economics, 40(19), 2443-2450. Available at: https://doi.org/10.1080/00036840701367606.

Rodrik, D., Subramanian, A., \& Trebbi, F. (2004). Institutions rule: The primacy of institutions over geography and integration in economic development. Journal of Economic Growth, 9(2), 131-165. Available at: https://doi.org/10.1023/B:JOEG.0000031425.72248.85.

Rogmans, T., \& Ebbers, H. (2013). The determinants of foreign direct investment in the Middle East North Africa region. International Journal of Emerging Markets 8(3), 240-257. Available at: https://doi.org/10.1 108/17468801311330310.

Roodman, D. (2006). How to do xtabond2: An introduction to difference and system GMM in Stata - Stata Journal. The Stata Journal 9(1), st0159.

Root, F. R. (1979). Empirical determinants of manufacturing direct foreign investment in developing countries. Economic Development and Cultural Change, 27(4), 751-767. Available at: https://doi.org/10.1086/451139.

Roy, S., \& Mandal, K. (2012). Foreign direct investment and economic growth: An analysis for selected Asian countries. Journal of Business Studies Quarterly, 4(1), 15-24.

Sahu, M. (2008). Inverted development and oil producers in sub-Saharan Africa: A study centre for African studies.

Saini, N., \& Singhania, M. (2018). Determinants of FDI in developed and developing countries: A quantitative analysis using GMM. Journal of Economic Studies, 45(2), 348-382. Available at: https://doi.org/10.1 108/JES-07-2016-0138.

Schneider, F., \& Frey, B. S. (1985). Economic and political determinants of foreign direct investment. World Development, 13(2), 161-175. Available at: https://doi.org/10.1016/0305-750X(85)90002-6.

Strobel, J., Nguyen Thanh, B., \& Lee, G. (2020). Effects of macroeconomic uncertainty and labor demand shocks on the housing market. Real Estate Economics, 48(2), 345-372. Available at: https://doi.org/10.1111/1540-6229.12232.

Tam, P. S. (2018). Global trade flows and economic policy uncertainty. Applied Economics, 50(34-35), 3718-3734. Available at: https://doi.org/10.1080/00036846.2018.1436151.

Wei, S. (1997). Why is corruption so much more taxing than tax? Arbitrariness killls. NBER Working Paper. Retrieved from: https://doi.org/10.3386/w6255.

Windmeijer, F. (2005). A finite sample correction for the variance of linear efficient two-step GMM estimators. Journal of Econometrics, 126(1), 25-51. Available at: https://doi.org/10.1016/j.jeconom.2004.02.005. 


\section{APPENDIX}

Table A1. Data Sources \& Sample Characteristics.

\begin{tabular}{l|l|l}
\hline Variable & Data Calculation & Source \\
\hline FDIin & Foreign direct investments as \% of GDP & WDI, World Bank \\
\hline GDP_g & Real GDP growth rate (annual \%) & WDI, World Bank \\
\hline Inf & Inflation (GDP deflator annual \%) & WDI, World Bank \\
\hline Gcf & Gross capital formation (\% of GDP) & WDI, World Bank \\
\hline $\mathrm{Hc}$ & $\begin{array}{l}\text { Human capital index, based on years of } \\
\text { schooling and returns to education, PWT 10.0 }\end{array}$ & PWT 10.0, Feenstra et al. (2015) \\
\hline $\mathrm{CO}_{2}$ & $\mathrm{CO} 2$ emissions (metric tons per capita) & WDI, World Bank \\
\hline $\mathrm{REER}$ & Real effective exchange rate (2010=100 index) & WDI, World Bank \\
\hline Trade & Trade openness (export-import/GDP) & WDI, World Bank \\
\hline IQ & Mean of six governance indicators & WGI, World Bank \\
\hline EPU & $\begin{array}{l}\Delta \text { Log (Country Economic Policy Uncertainty } \\
\text { index in December) }\end{array}$ & $\begin{array}{l}\text { Www.policyuncertainty.com provided } \\
\text { by Baker et al. (2016) }\end{array}$ \\
\hline FD_index & Financial development index, IMF & IMF-FD \\
\hline ExS_index & Exchange rate stability index & Aizenman, Chinn, \& Ito (2010) \\
\hline FO_index & Financial openness index & $\begin{array}{l}\text { Chinn \& Ito, 2006; Chinn. \& Ito, } \\
\text { 2008) }\end{array}$ \\
\hline
\end{tabular}

Table A1....continued.

\begin{tabular}{|c|c|c|c|}
\hline & Country & Region & Income Group \\
\hline 1 & Australia & East Asia \& Pacific & High income \\
\hline 2 & Brazil & Latin America \& Caribbean & Upper middle income \\
\hline 3 & Canada & North America & High income \\
\hline 4 & Chile & Latin America \& Caribbean & High income \\
\hline 5 & China & East Asia \& Pacific & Upper middle income \\
\hline 6 & Colombia & Latin America \& Caribbean & Upper middle income \\
\hline 7 & France & Europe \& Central Asia & High income \\
\hline 8 & Germany & Europe \& Central Asia & High income \\
\hline 9 & Greece & Europe \& Central Asia & High income \\
\hline 10 & India & South Asia & Lower middle income \\
\hline 11 & Ireland & Europe \& Central Asia & High income \\
\hline 12 & Italy & Europe \& Central Asia & High income \\
\hline 13 & Japan & East Asia \& Pacific & High income \\
\hline 14 & Korea, Rep. & East Asia \& Pacific & High income \\
\hline 15 & Mexico & Latin America \& Caribbean & Upper middle income \\
\hline 16 & Netherlands & Europe \& Central Asia & High income \\
\hline 17 & Russian Federation & Europe \& Central Asia & Upper middle income \\
\hline 18 & Singapore & East Asia \& Pacific & High income \\
\hline 19 & Spain & Europe \& Central Asia & High income \\
\hline 20 & Sweden & Europe \& Central Asia & High income \\
\hline 21 & United Kingdom & Europe \& Central Asia & High income \\
\hline 22 & United States & North America & High income \\
\hline
\end{tabular}


Table A2. Correlation Matrix.

\begin{tabular}{|c|c|c|c|c|c|c|c|c|c|c|c|c|c|}
\hline & FDI & $\overline{\text { GDP_g }}$ & Inf & Gef & Hc & $\mathrm{CO}_{2}$ & REER & Trade & IQ & $\overline{E P U}$ & $\begin{array}{c}\text { FD_ } \\
\text { index }\end{array}$ & $\begin{array}{l}\text { ExS }_{-} \\
\text {index }\end{array}$ & $\begin{array}{c}\text { FO_ } \\
\text { index }\end{array}$ \\
\hline GDP_g & $0.2233^{* * * *}$ & 1.00 & & & & & & & & & & & \\
\hline p-value & 0.0000 & & & & & & & & & & & & \\
\hline Inf & -0.0589 & $0.3118 * * *$ & 1.00 & & & & & & & & & & \\
\hline p-value & 0.2175 & 0.0000 & & & & & & & & & & & \\
\hline Gcf & -0.0179 & 0.5567 & 0.0295 & 1.00 & & & & & & & & & \\
\hline p-value & 0.7088 & 0.0000 & 0.5381 & & & & & & & & & & \\
\hline $\mathrm{Hc}$ & 0.0528 & $-0.3218^{* * *}$ & $-0.3247^{* * *}$ & $-0.3036^{* * *}$ & 1.00 & & & & & & & & \\
\hline$p$-value & 0.2691 & 0.0000 & 0.0000 & 0.0000 & & & & & & & & & \\
\hline $\mathrm{CO}_{2}$ & 0.0755 & -0.0821 & $-0.1402^{* *}$ & -0.0444 & $0.6254^{* * * *}$ & 1.00 & & & & & & & \\
\hline$p$-value & 0.1355 & 0.1045 & 0.0054 & 0.3817 & 0.0000 & & & & & & & & \\
\hline REER & 0.0245 & -0.0406 & $-0.3329 * * *$ & $0.2072 * * *$ & $0.2434 * * *$ & $0.1424 * *$ & 1.00 & & & & & & \\
\hline$p$-value & 0.6084 & 0.3952 & 0.0000 & 0.0000 & 0.0000 & 0.0047 & & & & & & & \\
\hline Trade & $0.5446^{* * * *}$ & $0.1733^{*} * *$ & $-0.1606^{* * * *}$ & 0.0721 & $0.1022^{* *}$ & 0.0614 & 0.0732 & 1.00 & & & & & \\
\hline p-value & 0.0000 & 0.0003 & 0.0007 & 0.1316 & 0.0320 & 0.2250 & 0.1252 & & & & & & \\
\hline IQ & $0.2520^{*} * * *$ & $-0.1764 * * *$ & $-0.5056^{* * *} *$ & $-0.1863^{* * *} *$ & $0.6412^{*} * *$ & $0.4703 * * *$ & $0.2258 * * *$ & $0.3120 * * *$ & 1.00 & & & & \\
\hline p-value & 0.0000 & 0.0003 & 0.0000 & 0.0001 & 0.0000 & 0.0000 & 0.0000 & 0.0000 & & & & & \\
\hline EPU & 0.0040 & 0.0663 & 0.0672 & 0.0496 & 0.0194 & 0.0432 & 0.0403 & -0.0102 & -0.0433 & 1.00 & & & \\
\hline p-value & 0.9331 & 0.1669 & 0.1612 & 0.3020 & 0.6865 & 0.3959 & 0.4018 & 0.8313 & 0.3792 & & & & \\
\hline FD_index & 0.0394 & $-0.5214^{* * * *}$ & $-0.4193^{* * *}$ & $-0.0937 * *$ & $0.6119 * * *$ & $0.5445 * * *$ & $0.2405 * * *$ & $0.1166^{* *}$ & $0.5900 * * *$ & 0.0272 & 1.00 & & \\
\hline p-value & 0.4102 & 0.0000 & 0.0000 & 0.0497 & 0.0000 & 0.0000 & 0.0000 & 0.0144 & 0.0000 & 0.5717 & & & \\
\hline ExS_index & $0.2217 * * * *$ & -0.0254 & $-0.2179^{* * *}$ & -0.0089 & $-0.1565 * * *$ & -0.0736 & 0.0437 & $0.1922 * * *$ & $0.1344 * * *$ & -0.0653 & $0.2021 * * *$ & 1.00 & \\
\hline$p$-value & 0.0000 & 0.5955 & 0.0000 & 0.8518 & 0.0010 & 0.1460 & 0.3599 & 0.0000 & 0.0059 & 0.1733 & 0.0000 & & \\
\hline FO_index & $0.1895^{* * * *}$ & $-0.3179^{* * *}$ & $-0.3960 * * *$ & $-0.3942 * * *$ & 0.4977 *** & $0.5483 * * *$ & $0.2250 * * *$ & 0.2429 **** & $0.6354 * * * *$ & 0.0142 & $0.4550^{*} * *$ & $0.2301 * * * *$ & 1 \\
\hline$p$-value & 0.0000 & 0.0000 & 0.0000 & 0.0000 & 0.0000 & 0.0000 & 0.0000 & 0.0000 & 0.0000 & 0.7677 & 0.0000 & 0.0000 & \\
\hline
\end{tabular}

Note: *, **, and $* * *$ denote significance levels at $10 \%, 5 \%$, and $1 \%$, respectively. 
Table A3. Institutional Quality, Economic Policy Uncertainty and FDI inflows (Two-step system GMM estimations).

\begin{tabular}{|c|c|c|c|c|c|c|}
\hline & (1) & \multicolumn{2}{|c|}{$(2)$} & \multicolumn{2}{|c|}{ (3) } & $(4)$ \\
\hline & Baseline & \multicolumn{2}{|c|}{ Institutions and FDI } & \multicolumn{2}{|c|}{ EPU and FDI } & $\begin{array}{l}\text { Institutions, } \\
\text { EPU and FDI }\end{array}$ \\
\hline \multirow[t]{2}{*}{ L.FDIin } & $0.6421 * * *$ & 0.1398 & -0.0114 & $0.6947 * * *$ & $0.6363 * * *$ & 0.2446 \\
\hline & $(0.0484)$ & $(0.1629)$ & $(0.0089)$ & $(0.1052)$ & $(0.0606)$ & $(0.1657)$ \\
\hline \multirow[t]{2}{*}{$\mathrm{GDP}_{-g}$} & $0.3171 * * *$ & $0.1341 * *$ & 0.0029 & $0.3011 * * *$ & $0.2946 * * *$ & $0.1490^{*}$ \\
\hline & $(0.0549)$ & $(0.0529)$ & $(0.0056)$ & $(0.0639)$ & $(0.0700)$ & $(0.0843)$ \\
\hline \multirow[t]{2}{*}{ Inf } & -0.1327 & $1.6091^{* * * *}$ & $0.0792^{* * * *}$ & -0.1094 & -0.0183 & $1.5526^{* * * *}$ \\
\hline & $(0.1099)$ & $(0.3929)$ & $(0.0205)$ & $(0.1272)$ & $(0.1681)$ & $(0.3843)$ \\
\hline \multirow[t]{2}{*}{ Gcf } & $-3.5102 * * *$ & 0.3527 & $0.3455^{* *}$ & $-2.8414^{* *}$ & -1.7736 & 0.3643 \\
\hline & $(1.2144)$ & $(3.7955)$ & $(0.1722)$ & $(1.2689)$ & $(1.2942)$ & $(3.6632)$ \\
\hline \multirow[t]{2}{*}{$\mathrm{Hc}$} & $1.6953^{* *}$ & $6.2762^{* * *}$ & 0.3229 & $2.4460^{* * * *}$ & $3.7953^{* * *}$ & $7.9607^{* * * *}$ \\
\hline & $(0.8641)$ & $(1.5547)$ & $(0.2143)$ & $(0.9470)$ & $(1.4154)$ & $(2.2409)$ \\
\hline \multirow[t]{2}{*}{$\mathrm{CO}_{2}$} & $-1.3755^{* *}$ & $-6.0206^{* * * *}$ & $-0.3743 * * *$ & $-1.7935^{* *}$ & $-2.6529 * *$ & $-6.3450^{* * * *}$ \\
\hline & $(0.7001)$ & $(1.7387)$ & $(0.1189)$ & $(0.7408)$ & $(1.0721)$ & $(1.6091)$ \\
\hline \multirow[t]{2}{*}{ REER } & $2.0807 * *$ & 1.4574 & 0.1620 & 1.8741 ** & 1.4902 & 1.7008 \\
\hline & $(0.8595)$ & $(1.4294)$ & $(0.1166)$ & $(0.8819)$ & $(1.0827)$ & $(1.1833)$ \\
\hline \multirow[t]{2}{*}{ Trade } & $0.3336^{*}$ & 0.2848 & $-0.0972 * * *$ & 0.2545 & $0.4657^{*} *$ & 0.6190 \\
\hline & $(0.1750)$ & $(0.6966)$ & $(0.0366)$ & $(0.2893)$ & $(0.2162)$ & $(0.7371)$ \\
\hline \multirow[t]{2}{*}{ IQ } & & $15.8052^{*}$ & & & & 10.7601 \\
\hline & & $(9.0404)$ & & & & $(7.8351)$ \\
\hline \multirow[t]{2}{*}{ FDI*IQ } & & & $1.2376^{* * * *}$ & & & \\
\hline & & & $(0.0232)$ & & & \\
\hline \multirow[t]{2}{*}{$\mathrm{EPU}$} & & & & -0.1013 & & $-0.3318^{* * *}$ \\
\hline & & & & $(0.0960)$ & & $(0.1243)$ \\
\hline \multirow[t]{2}{*}{ FDI*LEPU } & & & & & $-0.2093^{* *}$ & \\
\hline & & & & & $(0.0986)$ & \\
\hline \multirow[t]{2}{*}{ Constant } & -2.9498 & $-29.8340^{*}$ & $-1.7225^{* *}$ & -5.3839 & -10.4266 & $-32.7846^{* *}$ \\
\hline & $(5.2855)$ & $(15.7218)$ & $(0.7122)$ & $(5.6902)$ & $(7.4122)$ & $(13.5825)$ \\
\hline Observations & 276 & 276 & 276 & 276 & 276 & 276 \\
\hline Number of countries & 22 & 22 & 22 & 22 & 22 & 22 \\
\hline $\operatorname{AR}(2)$ p-value & 0.6150 & 0.4200 & 0.1060 & 0.5310 & 0.6100 & 0.5070 \\
\hline $\begin{array}{l}\text { Hansen's J-test p- } \\
\text { value }\end{array}$ & 0.5390 & 0.4090 & 0.5700 & 0.5300 & 0.6040 & 0.6120 \\
\hline
\end{tabular}

Table A4. Financial Openness, Exchange Rate Stability, Financial Development and FDI inflows (Two-step system GMM estimations).

\begin{tabular}{l|c|c|c}
\hline & $(\mathbf{1})$ & $\mathbf{( 2 )}$ & $\mathbf{( 3 )}$ \\
\hline L.FDIin & $\begin{array}{c}\text { Financial } \\
\text { Openness }\end{array}$ & $\begin{array}{c}\text { Exchange Rate } \\
\text { Stability }\end{array}$ & $\begin{array}{c}\text { Financial } \\
\text { Development }\end{array}$ \\
\hline GDP_g & $0.4188^{* * *}$ & $0.6298^{* * *}$ & $0.3847^{* * *}$ \\
\hline & $(0.0895)$ & $(0.1002)$ & $(0.1125)$ \\
\hline Inf & $0.2175^{* * *}$ & $0.2011^{* * *}$ & $0.2091^{* *}$ \\
\hline Gcf & $(0.0526)$ & $(0.0494)$ & $(0.0954)$ \\
\hline & $0.7404^{* * *}$ & 0.2769 & $0.9593^{* * *}$ \\
\hline Hc & $(0.2817)$ & $(0.2220)$ & $(0.3423)$ \\
\hline CO ${ }_{2}$ & 1.3101 & -0.3988 & -2.6109 \\
\hline REER & $(3.2655)$ & $(0.9572)$ & $(2.0965)$ \\
\hline & $5.0819^{* * *}$ & $5.4065^{* * *}$ & $4.8372^{* * *}$ \\
\hline Trade & $(1.4743)$ & $(1.7046)$ & $(1.7449)$ \\
\hline & $-4.0915^{* * *}$ & $-3.0702^{* * *}$ & $-4.9370^{* * *}$ \\
\hline FO_index & $(0.8409)$ & $(1.0762)$ & $(1.0269)$ \\
\hline & -0.8495 & & $4.4692^{* * *}$ \\
\hline & $(2.1930)$ & & $(1.2958)$ \\
\hline
\end{tabular}


Asian Economic and Financial Review, 2021, 11(6): 471-487

\begin{tabular}{l|c|c|c}
\hline ExS_index & & $3.4983^{* * *}$ & \\
\hline FD_index & & $(1.1469)$ & \\
\hline & & & $5.7537^{* *}$ \\
\hline Constant & & & $(2.5243)$ \\
\hline & -11.6541 & $-10.6649 * *$ & $-31.5772^{* * *}$ \\
\hline Observations & $(9.6778)$ & $(5.3306)$ & $(8.3086)$ \\
\hline Number of countries & 276 & 276 & 276 \\
\hline AR(2) p-value & 22 & 22 & 22 \\
\hline Hansen's J-test p-value & 0.9230 & 0.4950 & 0.9150 \\
\hline Note: Standard errors are in (). ${ }^{*}, *$ and ${ }^{* * *}$ denote significance levels at $10 \%, 5 \%$, and $1 \%$, respectively. & 0.4060 \\
\hline
\end{tabular}

Views and opinions expressed in this article are the views and opinions of the author(s), Asian Economic and Financial Review shall not be responsible or answerable for any loss, damage or liability etc. caused in relation to/arising out of the use of the content. 